\title{
PENINGKATAN PROFIT DAN PEMASARAN INDUSTRI MELALUI PEMBERDAYAAN WAWASAN KEUANGAN DAN PERANCANGAN WEBSITE
}

\author{
Sri Murni, Ignatia Sri Seventi P, Dini Octoria, \& Rahmawati \\ Universitas Sebelas Maret Surakarta, Indonesia \\ Email:murnidj@gmail.com
}

\begin{abstract}
Abstrak: Peningkatan Profit dan Pemasaran Industri melalui Pemberdayaan Wawasan Keuangan dan Perancangan Website. Tujuan penelitian ini adalah untuk meningkatkan profit dan pemasaran industri minyak atsiri di Wonogiri melalui pemberdayaan wawasan keuangan dan rancangan website. Penelitian ini merupakan penelitian cross sectional dengan subjek penelitian IKM CV Giri Putra dan CV Sekar Melati yang merupakan IKM penghasil minyak atsiri di Kecamatan Girimarto Kabupaten Wonogiri. Teknik pengumpulan data dilakukan melalui tiga tahapan yaitu studi pendahuluan, pengembangan desain, dan validasi model. Hasil penelitian menunjukkan bahwa pemberdayaan wawasan keuangan dan rancangan website terbukti telah meningkatkan profit dan pemasaran industri minyak atsiri di Wonogiri.

Kata kunci: Wawasan keuangan, Rancangan website, Pemasaran, Profit

Abstract: Profit Improvement and Industrial Marketing through Financial Insights Empowerment and Website Design. The purpose of this study is to increase profitability and marketing of "atsiri" oil industries in Wonogiri through the empowerment of financial insight and website design. This research was a cross sectional study. The subjects of this study are CV Putra and CV Sekar Melati which are small medium industry producing "atsiri" oil in Girimarto Wonogiri. Data was collected through three stages, namely a preliminary study, design, development and validation of models. The results showed that the empowerment of financial insight and design of the website has improved profit and marketing of "atsiri" oil industries in Wonogiri.
\end{abstract}

Keywords: Financial Insights, website design, Marketing, Profit

\section{PENDAHULUAN}

Wilayah Kecamatan Girimarto yang terletak di Kabupaten Wonogiri Pronvinsi Jawa Tengah merupakan daerah agraris, yang lahan pertanian di wilayah tersebut termasuk pertanian lahan kering (tegalan). Kegiatan ekonomi dan mata pencaharian sebagian besar penduduknya adalah sebagai petani pada lahan pertanian, yang mayoritas lahannya ditanami daun Nilam dan Cengkeh. Hasil pertanian tanaman nilam dan cengkih selama ini cukup melimpah karena didukung oleh lahan pertanian yang cukup luas.
Kondisi ini tentu saja menjadi keunggulan daerah Kabupaten Wonogiri, terlebih saat ini sudah berlangsungnya era Masyarakat Ekonomi Asean (MEA). Tanaman nilam dan cengkih ini memiliki nilai kebermanfaatan yang cukup tinggi, karena salah satu produk dari tanaman ini adalah minyak atsiriyang memiliki khasiat kesehatan utama untuk menghangatkan tubuh. Dengan mengoptimalkan produksi minyak atsiripada Kabupaten Wonogiri baik sebagai produk lokal dan produk ekspor, tentu saja akan 
menjadi keunggulan tersendiri bagi Indonesia di antara negara Asean lainnya.

Hasil pertanian tanaman nilam dan cengkih yang menunjukkan trend meningkat setiap tahunnya, tidak disertai dengan pendapatan yang meningkat bagi para pelaku Industri Kecil Menengah (IKM) minyak atsiri. Berdasarkan observasi pra penelitian yang dilakukan pada 10 Februari 2014, diketahui bahwa para pelaku IKM minyak atsiri belum memiliki pengelolaan keuangan yang baik. Hal ini dapat diketahui dari wawancara yang dilakukan kepada IKM minyak atisiri bahwa para pelaku produksi tidak memiliki catatan dan laporan keuangan dalam menjalankan produksinya. Jika ada IKM yang memiliki catatan keuangan, IKM tersebut tidak memisahkan keuangan pribadi dengan keuangan yang terkait dengan produksi minyak atisiri. Kondisi tersebut disebabkan karena sumber daya manusia IKM minyak atsiri memiliki keterbatasan wawasan keuangan. IKM yang tidak memiliki laporan keuangan, tentu saja akan mengalami kesulitan dalam mengajukan kredit pada pihak bank yang pada akhirnya akan mengganggu permodalam IKM.

IKM minyak atsiri juga masih memiliki kendala dalam melakukan pemasaran produk minyak atsiri. Selama ini produk minyak atsiri hanya dipasarkan pada wilayah Wonogiri dan daerah sekitarnya seperti Sukoharjo, Surakarta, dan Pacitan. Pemasaran yang dilakukan hanya pada daerah lokal belum mengarah ke tingkat nasional maupun ekspor. Hal tersebut disebabkan karena minimnya pengetahuan yang terkait dengan pemasaran dan pemanfaatan teknologi. Di era penggunaan internet seperti saat ini, kondisi geografis sudah tidak menjadi kendala karena dengan bantuan website para IKM minyak atsiri dapat memasarkan produknya di tingkat lokal, nasional, maupun internasional.

Selain permasalahan yang telah dikemukakan tersebut, hasil observasi pra penelitian menunjukkan beberapa permasalahan sebagai berikut:

1. Bahan Baku.

Perolehan bahan baku sering mengalami kesulitan karena tidak optimalnya penggunaan lahan untuk penanaman bahan baku.

2. Inovasi produk.

Minimnya pengalaman memicu minimnya inovasi yang dilakukan.

3. Manajemen keuangan.

Secara umum IKM belum melakukan pemilahan harta usaha, selain itu juga belum melakukan pembukuan secara baik.

4. Jumlah produksi.

Rendahnya jumlah produksi dan minimnya peralatan yang digunakan berakibat pada jumlah dan kualitas produksi.

5. Penentuan tarif.

Tidak ada tarif yang umum dan seragam di antara para IKM Minyak Atsiri.

Berdasarkan uraian latar belakang dan permasalahan di atas, dibutuhkan penguatan hubungan antara Perguruan Tinggi yaitu Universitas Sebelas Maret dan dunia kerja yaitu IKM minyak atsiri, dalam melakukan transfer ilmu pengetahuan dan teknologi. Tujuan penelitian ini adalah untuk meningkatkan profit dan pemasaran industri minyak atsiri di Wonogiri melalui pemberdayaan wawasan keuangan dan 
rancangan website. Dengan demikian transfer ilmu pengetahuan dan teknologi yang dimaksud dalam penelitian ini adalah wawasan keuangan dan rancangan website.

Pemberdayaan masyarakat melalui wawasan keuangan perlu disesuaikan dengan latar belakang pendidikan personil IKM minyak atsiri yang sebagian besar lulusan SMA dan SMK. Untuk itu wawasan keuangan yang diberikan adalah pengetahuan single entry bookkeeping yang diharapkan dapat meningkatkan pengetahuan dan keterampilan dalam menyusun informasi keuangan usaha dan pada akhirnya akan meningkatkan profit. Single entry bookkeeping merupakan pembukuan keuangan yang dilakukan oleh unit usaha dengan hanya mencatat setiap transaksi yang terjadi dengan pencatatan satu jurnal. Secara lebih spesifik Accounting Tools (2015: 1) menyebutkan bahwa, "The single entry system is centered on the results of a business that are reported in the income statement. The core information tracked in a single entry system is cash disbursements and cash receipts." (Sistem pencatatan tunggal berpusat pada hasil usaha yang dilaporkan dalam laporan laba rugi. Informasi inti pencatatan tunggal ini adalah pengeluaran kas dan penerimaan kas).

Selain melakukan pemberdayaan masyarakat melalui wawasan keuangan, penelitian ini juga memberdayakan masyarakat melalui perancangan website. Perancangan merupakan penggambaran, perencanaan, pembuatan sketsa dari beberapa elemen yang terpisah ke dalam satu kesatuan yang utuh dan berfungsi (Sardi, 2004: 27). Penelitian ini melakukan perancangan untuk memasarkan produk minyak atsiri ke pangsa pasar yang lebih luas. Website merupakan kumpulan halaman web yang saling terhubung dengan file-file saling terkait. Selanjutnya website terdiri dari page atau halaman, dan kumpulan halaman yang dinamakan home page. Home page berada pada posisi teratas, dengan halamanhalaman terkait berada di bawahnya. Pada umumnya setiap halaman di bawah homepage disebut child page, yang berisi hyperlink ke halaman lain dalam website (Gregorius, 2000: 30). Dengan demikian website akan memudahkan para surfer atau pengguna internet melakukan penelusuran informasi di internet. Dalam penelitian ini, informasi yang disajikan berupa produk minyak atsiri dengan menggunakan tampilan multimedia sehingga akan memiliki nilai lebih dalam pemasarannya.

\section{METODE}

Penelitian dengan judul, "Pemberdayaan masyarakat melalui wawasan keuangan dan perancangan website untuk meningkatkan profit dan pemasaran industri minyak atsiri di Wonogiri" merupakan jenis penelitian cross sectional dengan mempelajari subjek dan objek penelitian dalam jangka waktu tertentu. Subjek penelitian ini adalah IKM CV Giri Putra dan CV Sekar Melati yang merupakan IKM penghasil minyak atsiri di Kecamatan Girimarto Kabupaten Wonogiri.

Teknik pengumpulan data yang digunakan dalam penelitian ini dilakukan melalui tahapan sebagai berikut:

1. Tahap studi pendahuluan dilakukan dengan menerapkan pendekatan deskriptif kuantitatif.

2. Tahap pengembangan desain dengan menerapkan pendekatan deskriptif dan 
FGD, dilanjutkan dengan penerapan uji coba terbatas desain model dengan metode ekperimen (single one shot case study). Setelah ada perbaikan dari Uji terbatas. maka dilanjutkan dengan uji yang lebih luas dengan metode ekperimen (one group pretese-postest).

3. Tahap berikutnya adalah tahap validasi model dengan metode eksperimen quasi (pretest-posttest with control group desiqn) atau tahap Evaluasi.

Analisis data yang digunakan untuk tahun pertama dalam penelitian ini dapat diuraikan sebagai berikut:

1. Untuk memperkuat IKM merebut peluang dan memasuki pasar ekspor maka tahun pertama ditujukan untuk memperkuat wawasan keuangan dan perancangan website.

2. Perancangan pengembangan desain dengan melakukan pengujian uji judges atau uji di lapangan terbatas tentang kelayakan desain yang akan diimplementasikan. Uji lapangan terbatas menggunakan metode eksperimen model single one shot case studydengan menguji tiga kali pengujian yaitu:

a. Dengan menggunakan pengujian terbatas Uji coba 1

b. Dengan menggunakan pengujian terbatas Uji coba 2

c. Dengan menggunakan pengujian terbatas Uji coba 3

3. Dalam pengembangan desain apabila belum sempurna maka perludilakukan revisi sesuai kompetensi untuk aktivitas tindakan perbaikan pengembangan desain. Revisi desain dilakukan apabila:
a. Dalam pemakaian kondisi nyata terdapat kekurangan dan kelemahan.
b. Uji pemakaian desain baru perlu dievaluasi untuk perbaikan desain.

4. Dalam Implementasi Pengembangan Desain perlu adanya pembinaan, pengawasan, dan evaluasi supaya tidak terjadi penyimpangan.

5. Validasi desain merupakan:

a. Proses kegiatan untuk menilai apakah rancangan desain dalam hal ini desa in baru secara rasional akan lebih efektif dari yang lama atau tidak.

b. Dikatakan secara rasional, karena validasi ini bersifat penilaian berdasarkan pemikiran rasional, bellum fakta di lapangan.

c. Validasi dapat dilakukan dengan cara menghadirkan beberapa pakar atau tenaga ahli yang sudah berpengalaman untuk produk baru tersebut.

d. Sehingga selanjutnya dapat diketahui kelemahan dan kekuatannya. Validasi desain dapat dilakukan dalam forum diskusi.

\section{HASIL DAN PEMBAHASAN}

Penelitian ini beroperasi dengan lancar dan melembaga (memiliki prospek mandiri dan berkelanjutan) melalui Pembentukan Kelompok Belajar Usaha (KBU) dan berkesinambungan dengan didampingi IKM CV Giri Putra dan CV Sekar Melati. Personil sebanyak 20 orang dari petani minyak atsiri akan memiliki empat jenis kecakapan hidup yaitu: 1) Kecakapan Pribadi yaitu kecakapan untuk mengenal diri sendiri orang berpikir secara rasional dan kecakapan untuk tampil dengan kepercayaan diri yang mantap. 2) 
Kecakapan Sosial yaitu kecakapan untuk berkomunikasi melakukan kerja sama, bertenggang rasa dan memiliki kepedulian serta tanggung jawab sosial dalam kehidupan bermasyarakat. 3) Kecakapan Akademik yaitu kecakapan untuk merumuskan dan memecahkan masalah yang dihadapi melalui proses berpikir kritis, analisis, dan sistematis serta memiliki kemampuan untuk melakukan penelitian, eksplorasi, inovasi dan kreasi melalui pendekatan ilmiah. 4) Kecakapan Vokasional yaitu kecakapan yang berkaitan dengan bidang keterampilan kerajinan tenun yang dapat dipergunakan untuk bekerja sebagai karyawan maupun usaha mandiri.

Selanjutnya petani minyak atsiri akan memiliki kemampuan kewirausahaan yang meliputi: Kemampuan untuk mengelola dan menyusun perencanaan usaha, Kemampuan untuk melakukan pengembangan usaha melalui kemampuan berpikir kreatif dan inovatif, Kemampuan untuk melakukan usaha secara profesional dan mandiri. Keterlibatan kemitraan secara intensif dengan pihak yang akan terkait dalam perencanaan, pelaksanaan dan pengawasan penelitian pengembangan ini antara lain: 1) Lembaga Pemerintah Desa/Camat untuk rekrutmen petani. 2) Dinas perindustrian koperasi dan UMKM untuk permodalan. 3) Dinas Pariwisata Kabupaten Wonogiri. 4) Universitas Sebelas Maret Surakarta sebagai tim peneliti. 5) IKM minyak atsiri di Kabupaten Wonogiri.

Peningkatan kinerja industri mitra setelah dilakukannya pemberdayaan masyarakat melalui wawasan keuangan dan perancangan website dapat ditunjukkan dengan pencapaian sebagai berikut: 1) meningkatkan jumlah keuntungan, karyawan dan investasi, serta perluasan wilayah pemasaran. 2) Meningkatkan ketrampilan petani dalam membuat perencanaan dan mengelola usaha minyak atisiri sehingga memperoleh penghasilan yang layak untuk memenuhi kebutuhan hidupnya. 3) Menumbuhkembangkan wawasan keuangan di kalangan petani sehingga memiliki etos kerja tinggi serta dapat menghasilkan karyakarya unggul yang mampu bersaing di pasar lokal, nasional, dan internasional. 4) Meningkatkan kemampuan pengrajin dalam mengelola sumber daya alam, sosial, budaya dan lingkungan serta mampu memanfaatkan beraneka teknologi di bidang usaha perkebunan minyak atsiri. 5) Memiliki kemampuan memahami diri sendiri, orang lain dan lingkungan serta kemampuan bekerja dalam tim baik sektor formal maupun informal.

Metode pemilihan iptek yang digunakan dalam implementasi kegiatan yaitu: Observasi dimaksudkan untuk mengamati produksi minyak atsiridan proses pembuatannya di Kecamatan Girimarto, Kabupaten Wonogiri. Tim peneliti dengan petani menentukan konsep yang tepat dalam penentuan desain sehingga tahu desain yang banyak yang diminati konsumen, juga menentukan diversifikasi produk baru yang akan dibuat. Tim peneliti juga melakukan observasi guna menemukan kelemahan dan kelebihan: penggunaan mesin, melihat kekurangan dan kelebihan serta pembenahan manajemen keuangan, kerja bengkel, dan operasional usaha. Pendampingan secara individual dimaksudkan untuk mengetahui potensi 
secara individu dari masing-masing petani untuk bisa dikembangkan secara optimal.

Dari permasalahan yang telah dikemukakan, alternatif solusi yang ditawarkan bagi petani minyak atsiri di Kecamatan Girimarto, Kabupaten Wonogiri adalah agar mereka mampu melakukan pemberdayaan diri dengan bersikap mandiri dan dapat merintis usaha melalui ketrampilan/skill yang memadai. Pelatihanpelatihan yang diperlukan adalah:

1. Training wawasan keuangan.

2. Training pengembangan sikap mental berwirausaha.

3. Training manajemen keuangan bagi peserta.

4. Training perancangan website.

5. Sukses Story dengan menghadirkan praktisi bisnis terkait dan studi banding ke Wonogiri.

Untuk itu kegiatan yang telah dilakukan yaitu:

1. Persiapan:

a. Menyusun materi dan instrumen untuk seleksi dan perekrutan bagi peserta pelatihan.

b. Koordinasi dengan stakeholder terkait yaitu IKM CV Giri Putra dan IKM CV Sekar Melati di Kecamatan Girimarto, Kabupaten Wonogiri, Provinsi Jawa Tengah.

c. Koordinasi dengan instruktur yang meliputi dosen-dosen dari Universitas Sebelas Maret yang terkait maupun dari praktisi teknis terkait.

d. Penyusunan bahan $/$ modul/materi pelatihan.

2. Perekrutan:
Peserta yang mengikuti pelatihan sebanyak xx petani.

3. Pelatihan:

Pelatihan diberikan dalam bentuk in house training maupun out house training.

a. Pelatihan wawasan keuangan diberikan oleh Dosen Universitas Sebelas Maret dalam bentuk in house training maupun out house training.

b. Pelatihanperancangan website.

c. Pelatihan manajemen keuangan dalam bentuk pelatihan praktis, perpajakan koperasi, pengelolaan usaha di lakukan dalam in house trainingoleh Universitas Sebelas Maret dengan dibantu mahasiswa UNS.

d. Success Story menghadirkan pembicara praktisi di bidang usaha terkait dari IKM CV Giri Putra

e. Pendampingan teknis produksi, pengelolaan usaha, manajemen keuangan, serta melakukan pembentukan jaringan usaha untuk pemasaran hasil produksi ke depan.

Setelah mengikuti kegiatan training/ pelatihan dari seluruh rangkaian materi, peserta akan dievaluasi:

1. Pada akhir program pelatihan, peserta secara individu diwajibkan dapat membuat laporan keuangan atas IKM yang dikelolanya.

2. Pada akhir program peserta wajib menunjukkan hasil rancangan website yang akan digunakan untuk mengioptimalisasik bidang pemasaran.

3. Menghadirkan pengusaha mitra terkait dengan lingkup usaha lokal, nasional, maupun internasional untuk melihat 
hasil produksi peserta dalam rangka meningkatkan profit.

Pelaksana kegiatan adalah:

1. Dosen-dosen materi terkait dari Universitas Sebelas Maret.

2. Praktisi teknis dari pengusaha terkait.

3. Praktisi dari industri terkait.

4. Instansi dinas perindustrian dan IKM minyak atsiri sebagai istitusi yang memiliki kompetensi pada SDM peserta pelatihan terkait.

5. Pengrajin yang masih eksis dan memiliki prospek pengembangan usaha.

Sasaran kegiatan adalah:

1. Kriteria Sasaran Peserta Didik

a. Memiliki minat belajar/berusaha.

b. Penduduk usia produktif (18-35 tahun) perempuan maupun laki-laki.

c. Minimal berpendidikan SMA.

2. Berdomisili lokasi di IKM minyak atsiri di Desa Girimarto.

3. Cara Rekruitment Peserta Didik
a. Sosialisasi
b. Pendaftaran
c. Seleksi
d. Pelatihan

Strategi pembelajaran dilaksanakan dengan cara sebagai berikut:

1. Berkelompok.

Untuk tujuan efisiensi dan efektivitas strategi pembelajaran dilakukan dengan model pendekatan kelompok melalui pembentukan enam kelompok masingmasing 5 orang, jumlah peserta didik seluruhnya sebanyak 20.

2. Pendekatan Andralogi.

Pendekatan secara personal sesuai kebutuhan dan kemampuan pribadi peserta didik dengan meminimalkan pendekatan yang menjurus pendekatan instruksional.

3. Rasio mata pelajaran teori dan praktek adalah $20 \%$ dibanding $80 \%$.

Tempat pelaksanaan penelitian di Kecamatan Girimarto dan Universitas Sebelas Maret. Teknik pengumpulan data untuk mengetahui analisis kebutuhan petani minyak atsiri adalah menggunakan kuesioner. Instrumen dalam metode kuesioner menggunakan lembar kuesioner yang berisi sejumlah pertanyaan tertulis yang harus dijawab oleh responden. Secara keseluruhan ada 84 butir pertanyaan dengan rincian:

1. Data Pribadi Responden

Terdiri dari 8 butir pertanyaan meliputi: status responden, jenis kelamin, tingkat pendidikan, jumlah keluarga, status usaha, lama usaha, terbentuknya usaha, dan pengalaman mengikuti pelatihan.

2. Aspek Kewirausahaan.

Terdiri dari 11 butir pertanyaan yaitu 10 butir pertanyaan tentang jiwa wirausaha dan 1 butir pertanyaan tentang partisipasi dalam pelatihan kewirausahaan.

3. Aspek Keuangan

Terdiri dari 17 butir pertanyaan tentang kondisi objektif keuangan usaha serta 1 item pertanyaan tentang partisipasi dalam pelatihan pengelolaan keuangan usaha.

4. Aspek Produksi

Terdiri dari 17 butir pertanyaan tentang kondisi objektif kegiatan produksi dan 1 butir pertanyaan tentang partisipasi dalam pelatihan IKM minyak atsiri.

5. Aspek Pemasaran 
Terdiri dari 18 butir pertanyaan tentang kondisi objektif kegiatan pemasaran serta 1 butir pertanyaan tentang partisipasi dalam pelatihan pemasaran usaha.

\section{Aspek Manajemen dan Organisasi}

Terdiri dari 5 butir pertanyaan tentang karakteristik usaha, 8 item pertanyaan tentang kondisi objektif manajemen usaha, dan 1 butir pertanyaan tentang partisipasi dalam pelatihan manajemen usaha.

Berdasarkan instrumen yang telah diisi, untuk data pribadi responden dapat diketahui bahwa responden dengan status kepala keluarga sebanyak $85 \%$ dan $15 \%$ berstatus sebagai istri. Begitu pula dengan jenis kelamin, yaitu $85 \%$ pria dan $15 \%$ wanita. Untuk tingkat pendidikan responden, sebanyak 70\% lulusan SD, 15\% lulusan SLTP, dan $15 \%$ lulusan SLTA, dan tidak ada responden yang lulusan akademi atau perguruan tinggi. Sebanyak $50 \%$ responden memiliki tanggungan keluarga sebanyak 3-5 orang, dan responden lainnya memiliki tanggungan kurang dari 2 orang. Usaha minyak atsiri merupakan pekerjaan pokok responden sebanyak $75 \%$ dan $25 \%$ responden menjadikan usaha minyak atsiri sebagai pekerjaan sampingan. Untuk lama usaha minyak atsiri, sebanyak 50\% responden sudah menjalankan usaha selama lebih dari lima tahun. Untuk keterbentukan usaha, $90 \%$ responden membentuk usaha minyak atsiri karena hasil usaha sendiri, sedangkan untuk keikutsertaan responden dalam pelatihan sebanyak $95 \%$ responden belum pernah mengikuti pelatihan.

Dengan mengacu pada data pribadi responden tersebut, selanjutnya dilakukan analisis kebutuhan pelatihan (Training Need Analysis) untuk menyesuaikan isi latihan dengan kebutuhan peserta pelatihan yaitu petani minyak atsiri. Penyusunan analisis kebutuhan pelatihan dilakukan dengan pendekatan konsep enterprising usaha kecil. Enterprising usaha kecil adalah usaha kecil yang dikelola dengan pendekatan perusahaan atau usaha kecil yang menerapkan fungsi-fungsi manajemen di dalam pengelolaan usahanya. Fungsi-fungsi manajemen tersebut adalah perencanaan, pengorganisasian, pelaksanaan, dan pengendalian.

Kegiatan usaha kecil pada dasarnya meliputi kegiatan-kegiatan yang menyangkut produksi/teknologi, pemasaran, pengelolaan keuangan/permodalan serta manajemen usaha. Dari paparan mengenai gambaran usaha petani di wilayah penelitian dapat disimpulkan bahwa hambatan yang melekat pada usaha petani adalah pada miskinnya akses teknologi, keterbatasan akses pemasaran, keterbatasan permodalan/ keuangan dan kurangnya manajerial skill. Dengan beberapa kelemahan yang melekat tersebut maka aspek analisis kebutuhan pelatihan akan berkaitan dengan aspek produksi, pemasaran, keuangan, dan manajemen usaha pengrajin. Penelitian dari Harvard University menunjukkan bahwa kunci keberhasilan wirausaha $85 \%$ ditentukan oleh sikap mental/jiwa kewirausahaan dan hanya $15 \%$ ditentukan oleh keahlian teknis. Merujuk pada hasil penelitian tersebut, aspek kewirausahaan, keuangan, produksi, pemasaran, dan manajemen organisasi merupakan aspek yang diperhitungkan dalam melakukan analisis kebutuhan pelatihan. 
Pembahasan berikut mengenai kelima aspek tersebut yang berkaitan dengan analisis kebutuhan pelatihan didasarkan pada hasil analisis dari data primer yang dikumpulkan, yaitu:

\section{Kewirausahaan}

Dari jawaban responden terhadap kesepuluh butir pertanyaan mengenai aspek kewirausahaan, identifikasi derajat jiwa kewirausahaan yang dimiliki oleh responden adalah sebagai berikut:

a. Percaya Diri

Sebanyak $100 \%$ dari responden menyatakan memiliki rasa percaya diri dalam melakukan pekerjaan sebagai petani minyak atsiri.

b. Motivasi Diri

Sebanyak $100 \%$ dari responden memiliki motivasi diri untuk mencapai tujuan.

c. Menyukai Tantangan

Jumlah responden yang menyukai tantangan dalam pekerjaan sebanyak $100 \%$.

d. Kepemimpinan

Sebanyak $85 \%$ dari responden tidak terbiasa mengambil peran pemimpin dalam kelompok dan 15\% sisanya terbiasa mengambil peran kepemimpinan.

e. Membaca dan mengikuti kursus Sebesar $65 \%$ dari responden yang memanfaatkan kesempatan untuk memperluas pengetahuan dengan membaca dan mengikuti kursus sedangkan $35 \%$ sisanya tidak berkeinginan untuk memperluas pengetahuan.

f. Komunikasi
Semua responden menyatakan dapat berkomunikasi dengan orang lain.

g. Pendengar yang Baik

Semua responden menyatakan dapat menjadi pendengar yang baik.

h. Prestasi

Sebanyak $90 \%$ responden mampu mengembangkan prestasi dan $10 \%$ belum mampu.

i. Citra Diri

Sebanyak 95\% dari responden menyatakan memiliki citra diri yang positif sedangkan sisanya sebanyak $5 \%$ menyatakan tidak memiliki citra diri yang positif.

j. Pengambilan Keputusan

Sebanyak $80 \%$ dari responden menyatakan mampu membuat keputusan dengan mudah dan penuh keyakinan sedangkan sisanya sebanyak $20 \%$ menyatakan tidak.

k. Pentingnya pelatihan

Semua responden menyatakan pentingnya pelatihan.

2. Keuangan

Gambaran umum mengenai aspek keuangan usaha kecil adalah permodalan sebagian besar bersumber dari bank/koperasi (55\%), dana operasional tidak cukup tersedia (40\%), hanya sebagian petani minyak atsiri memiliki rekening di bank (45\%), pengelolaan keuangan ditangani pemilik (90\%), kesulitan mengakses kredit perbankan (85\%), modal kerja usaha berbentuk tagihan (100\%) dengan kondisi lancar (10\%) sedangkan aktiva lancar berupa persediaan barang dagangan jumlahnya cukup (90\%). Kinerja usaha dilihat dari keuntungan selama tiga tahun terakhir 
menunjukkan kecenderungan stabil (90\%).

Workshop Model Pelatihan Penyempurnaan akan dilakukan melalui forum workshop dengan narasumber bidang terkait (IKM minyak atsiri) disusun bahan ajar/modul sebagai materi yang akan disampaikan dalam proses pembelajaran. Dengan demikian diharapkan para pengrajin minyak atsiri dapat memiliki wawasan keuangan dasar, yang dapat digunakan untuk mengelola keuangan IKM minyak atsiri, yang pada akhirnya akan meningkatkan profit petani minyak atsiri.

3. Produksi

Sistem produksi minyak atsiri adalah dengan sistem yang mengacu pada hasil panen harian, yaitu sebanyak $100 \%$ petani menggunakan sistem produksi harian. Sebagian besar pengrajin (70\%) mengalami kemudahan dalam pengadaan bahan baku, dengan tingkat kualitas panen yang tidak menentu sebesar 90\%. Kondisi riil usaha kecil dilihat dari aspek pengelolaan produksi dapat diidentifikasi dari jawaban 7 butir pertanyaan yang diberikan oleh responden. Derajat pengelolaan kegiatan produksi dapat diketahui dengan memberikan skor 0 untuk jawaban "Tidak Ada", dan memberikan skor 1, 2 dan 3 bagi jawaban "Ada" dengan kondisi "kurang", "cukup" dan "baik".

a. Perencanaan Produksi Sebanyak $35 \%$ responden telah membuat perencanaan produksi dengan kategori "cukup baik".

b. Perencanaan Kualitas Produksi
Secara sederhana $60 \%$ responden telah mampu merencanakan kualitas produksi.

c. Perencanaan Pengadaan Peralatan Sebanyak $65 \%$ responden tidak melakukan perencanaan dalam pengadaan peralatan produksi yang digunakan.

d. Pengawasan Penggunaan Peralatan Sebanyak $80 \%$ responden tidak melakukan pengawasan dalam penggunaan peralatan.

e. Administrasi Produksi

Sebanyak 90\% responden tidak menyelenggarakan kegiatan administrasi produksi.

f. Pengawasan Kualitas Produksi

Semua responden $80 \%$ belum melaksanakan pengawasan kualitas dalam proses produksi.

g. Keselamatan dan Kesehatan Kerja Sebanyak $80 \%$ responden tidak menyelenggarakan kegiatan yang berkaitan dengan upaya keselamatan dan kesehatan kerja dalam proses produksinya.

Alasan responden tertarik mengikuti pelatihan wawasan keuangan minyak atsiri dan perancangan website antara lain adalah produksi dapat dilakukan dengan peralatan yang mereka miliki (80\%), desain menarik (100\%), prospek permintaan cukup bagus (100\%) dengan prospek keuntungan cukup menjanjikan (100\%).

\section{Pemasaran}

Gambaran umum mengenai kegiatan pemasaran minyak atsiri yang dilakukan oleh petani yaitu distribusi produk dilakukan melalui pemilik (95\%) dengan 
wilayah pemasaran lokal sebesar $85 \%$. Dengan kondisi pembayaran penjualan dilakukan secara tunai atau kontan $100 \%$. Selama kurun waktu tiga tahun terakhir, kinerja usaha menunjukkan kecenderungan stabil yang dibuktikan dari omzet penjualan sebesar $85 \%$ dan tingkat permintaan konsumen sebesar 85\%. Untuk persaingan sesama petani minyak atsiri menunjukkan $90 \%$ ada faktor persaingan. Kondisi objektif kegiatan pemasaran usaha responden diidentifikasi dari jawaban 11 butir pertanyaan kepada responden yang meliputi aspek antara lain: perencanaan pemasaran, strategi pemasaran, dan keterampilan menjual. Derajat pengelolaan usaha diketahui dengan memberikan skor 0 untuk jawaban "Tidak Ada", serta skor 1,2 dan 3 untuk jawaban "Ada" dalam kondisi "kurang", "cukup" dan "baik".

a. Perencanaan Target Penjualan Sebanyak 50\% responden tidak merencanakan target penjualan dan $50 \%$ sisanya membuat perencanaan namun masih dalam kondisi yang kurang sempurna.

b. Pencatatan Penjualan Sebanyak $75 \%$ responden membuat pencatatan penjualan.

c. Penetapan Harga Jual Sebanyak $65 \%$ responden belum melakukan perhitungan harga jual produk.

d. Memposisikan Produk Sebanyak 65\% responden belum melakukan upaya memposisikan produk di pasaran dengan variabel harga. e. Perencanaan Pemasaran

Sebanyak $50 \%$ responden sudah membuat rencana pemasaran, walaupun perencanaan yang dibuat dalam bentuk yang masih sederhana sedangkan $50 \%$ responden lainnya belum membuat perencanaan pemasaran.

f. Saluran Distribusi

Sebanyak 55\% responden memilih saluran distribusi sederhana yaitu menggunakan pengumpul yang mendatangi rumah responden sedangkan $45 \%$ responden menjual langsung ke pasar.

g. Promosi

Sebanyak $50 \%$ responden melakukan kegiatan promosi sederhana secara "getok tular" sedangkan 50\% sisanya tidak melakukan kegiatan promosi.

h. Peramalan Permintaan

Sebanyak $25 \%$ responden membuat ramalan permintaan melalui feeling/intuisi sedangkan sisanya belum melakukan peramalan permintaan.

i. Situasi Persaingan

Sebanyak 65\% responden tidak mengamati situasi persaingan secara visual tanpa melakukan penelitian sedangkan sisanya memberikan perhatian.

j. Target Pasar

Sebanyak 35\% responden menentukan target pasar bagi produknya, sedangkan $65 \%$ responden lainnya tidak menentukan target pasar bagi produknya.

k. Ketrampilan Menjual 
Sebanyak $25 \%$ belum memiliki keterampilan dalam melakukan penjualan.

Selanjutnya untuk partisipasi dalam pelatihan pemasaran, sebanyak $100 \%$ responden merasakan perlu mengikuti pelatihan pemasaran, yang dalam penelitian ini berupa perancangan website.

5. Manajemen dan Organisasi

Secara umum profil usaha pengrajin adalah berbentuk usaha perorangan (70\%), dengan skala usaha kecil (95\%) dan jenis usaha adalah perdagangan (90\%), yang dapat dikatakan sebagai industri rumah tangga (home industry) karena rata-rata memiliki tenaga kerja kurang dari 5 orang (65\%).Terbentuknya usaha adalah dari hasil usaha sendiri (100\%) dengan lama usaha sebagian besar di atas 5 tahun.

Kondisi pengelolaan usaha pengrajin digali dengan 8 butir pertanyaan yang meliputi aspek perijinan usaha, perencanaan usaha serta aspek pengorganisasian. Derajat pengelolaan usaha diketahui dengan memberikan skor 0 untuk jawaban "Tidak Ada" serta skor 1, 2 dan 3 untuk jawaban "Ada" dalam kondisi "kurang", "cukup" atau "baik".

a. Perijinan Usaha

Sebanyak $80 \%$ dari responden tidak memiliki perijinan usaha (SIUP, TDP, NPWP, Akte Pendirian) dan hanya $20 \%$ responden yang memiliki SIUP.

b. Pembagian Tugas dan Wewenang Sebanyak 50\% dari responden tidak melakukan pembagian tugas dan mendelegasikan wewenang, sisanya melakukannya dalam kondisi "kurang", "cukup" dan "baik".

c. Deskripsi Pekerjaan

Sebanyak 75\% dari responden tidak memiliki uraian tugas secara jelas, dan sisanya memiliki dalam kondisi "kurang", "cukup" dan "baik".

d. Peraturan Gaji dan Kepegawaian Sebanyak $70 \%$ dari responden tidak memiliki peraturan gaji dan kepegawaian, dan sisanya menyatakan memiliki akan tetapi dalam kondisi yang kurang baik.

e. Perencanaan Usaha

Sebanyak 60\% responden tidak membuat perencanaan usaha, dan mayoritas sisanya membuat dengan kondisi kurang baik dan cukup baik.

f. Pengarahan Kegiatan

Sebanyak $40 \%$ responden tidak melakukan pengarahan dalam pelaksanaan kegiatan, sisanya melakukan dengan kurang baik, cukup baik dan baik.

g. Koordinasi dan Komunikasi

Sebanyak $45 \%$ responden tidak melaksanakan koordinasi dan komunikasi dalam pelaksanaan kegiatan, dan sisanya melaksanakannya dengan kurang baik, cukup baik dan baik.

h. Pengawasan Kegiatan

Sebanyak 65\% responden tidak melakukan pengawasan terhadap jalannya kegiatan, 35\% melaksanakan pengawasan dengan cukup baik dan baik.

Selanjutnya sebanyak $100 \%$ dari responden menyatakan setuju untuk 
Jurnal Economia, Volume 12, Nomor 1, April 2016

berpartisipasi dalam pelatihan

manajemen usaha.

\section{DAFTAR PUSTAKA}

\section{SIMPULAN}

Hasil Tahun I (2016) meliputi: a) Melakukan Training Need Analysis bagi petani minyak atsiri. b) Mengembangkan model dan modul pelatihan wawasan keuangan bagi petani minyak atsiri dan diversifikasi bahan baku. c) Perancangan website bagi petani minyak atsiri. d). Pelatihan wawasan keuangan dan perancangan website serta kewirausahaan. e) Tersedianya alat yang memadai. Profit atau pendapatan petani minyak atsiri meningkat karena adanya pemberdayaan wawasan keuangan dan inovasi pemasaran yang dilakukan oleh petani minyak atsiri.

Accounting Tools. (2016) What is a single entry systems? Diakses dari http://www.accountingtools.com/questi ons-and-answers/what-is-a-single-entrysystem.htmlpada tanggal 11 Januari 2016.

Gregorius, Agung. (2000) Membuat Hompage Interaktif Dengan CGI/PERL. Jakarta: PT. Elex Media Komputindo.

Rahmawati, dkk. (2016) Pengembangan Kewirausahaan Kecil dan Menengah Batu Permata. Surakarta: UNS Press.

Sardi, Irawan. (2004)Manajemen, Desain dan Pengembangan Situs Web. Jakarta: PT. Elex Media Komputindo. 